\title{
Variation of Soil Strength with Height to Diameter Ratios of Test Specimen
}

\author{
Md. Golam Gaffar Khan", H Golam Morshed, Sanuar Ahmed Saikat \\ Department of CE, AUST, Dhaka, Bangladesh
}

DOI: $10.36348 /$ sjce.2019.v03i06.002

| Received: 28.10.2019 | Accepted: 04.11.2019 | Published: 21.11.2019

*Corresponding author: Md. Golam Gaffar Khan

Abstract

The aim of this project was to find out the strength of the soil samples with different height to diameter ratio. To compare the similar properties of different samples identical soil samples must be required. To reach up to this goal reconstituted samples were used to find the strength of them. Unconfined compression test were performed on the reconstituted soil specimen to investigate the variation of strength with the variation of specimen height to diameter ratio (H/D).The undrained shear strength of clays is commonly determined from an unconfined compression test which is necessary for the determination of the bearing capacity. It can be performed on both undisturbed and remolded specimen. In order to assure and predict the longibility and settlements of the structure due to load it is very important. H/D ratio of between 2 and 3 is generally recommended by accepted scientific and technical authorities. Nevertheless, published reports on the effect of specimen shape on soil strength are scarce. The value of test decreases significantly with increasing H/D ratio. It is less steep when the ratio is between 1.25 and 2.50. The soil samples used for this project are collected from four different locations in Dhaka. The test was performed on undisturbed soil specimen. In addition few more tests are done to know the index properties of soil. The range of variation of the ratios was 1.0 to 2.5 in this project. It was seen that the strength of soil samples was almost same for the range of ratio 1.75 to 2.5 .

Keywords: Soil Strength, Specimen, H/D Ratio.

Copyright @ 2019: This is an open-access article distributed under the terms of the Creative Commons Attribution license which permits unrestricted use, distribution, and reproduction in any medium for non-commercial use (NonCommercial, or CC-BY-NC) provided the original author and source are credited.

\section{INTRODUCTION}

Geotechnical engineering is a discipline that deals with soil and rock behavior in an engineering perspective. It is the specialty of Civil Engineering which deals with the property and behavior of soil and rock in engineering purpose. It also involves assessing slope stability and the risk of landslides, rock fall and avalanches. Geotechnical Engineering uses principal of soil mechanics and rock mechanics to investigate subsurface conditions and materials. To obtain different properties of soil, laboratory tests are performed on collected undisturbed and disturbed soil samples while field tests are performed on sub soil at in situ condition following mainly standard ASTM methods. In the Geotechnical engineering laboratory, tests like specific gravity, moisture content, grain size distribution by hydrometer etc. are done to know the index properties of soil and to know engineering properties major test such as unconfined compression test is performed with sample's height to diameter (H/D) ratio. Unconfined compression test is a special type of unconsolidated undrained test that is commonly used for clay specimens. Normally, the height to diameter ratio is taken within the range of 2.0 to 2.5 . Usually within this range the properties of soil are approximately similar [1-3].

This test maybe conducted on undisturbed or remoulded cohesive soils. Due to this test we can check the various parameters of the soil like:

- Unconfined compressive strength

- Sensitivity of soil

- Shear parameters of the soil, etc. 


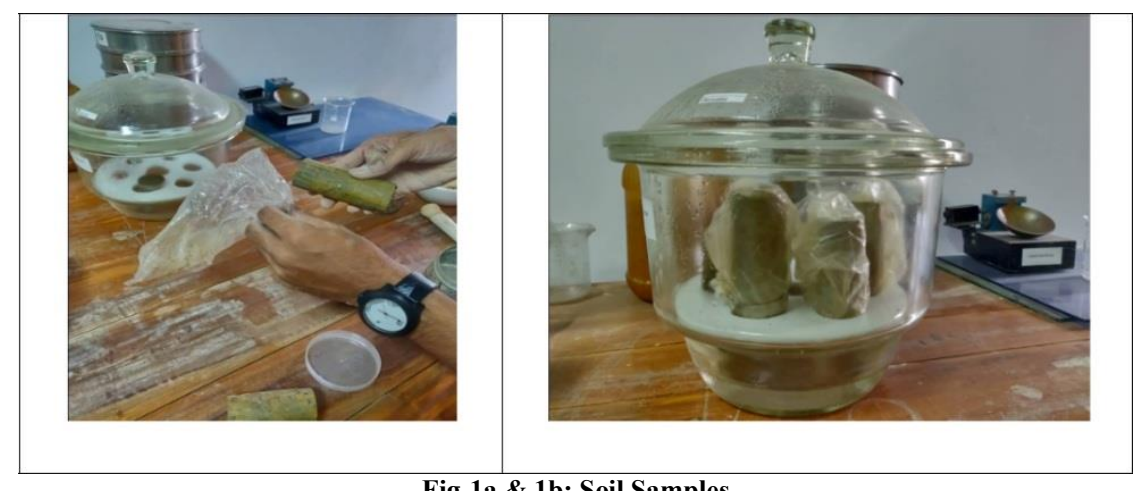

Fig-1a \& 1b: Soil Samples

The unconfined compression test is the simplest, easiest and least expensive test for investigating the shear strengths of soil which is a modified version of the tri-axial compression test.

This research has been conducted by taking different ratios of height to diameter unconfined compression test along with few other tests were performed to know the soil's index and engineering properties [4-6].

\section{OBJECTIVES \\ General Objective}

The main objective of this study is to evaluate the variation of soil strength with height to diameter ratios of test specimen.

\section{Specific Objectives}

- To compare the shear strength, failure strain and modulus of elasticity of the soil for the variation of H/D ratios of the test Specimen.

- To know about the physical and index properties of soil samples collected from different locations.

- To obtain the difference between experimental values from the standard values in test performed.

- To compare stress-strain curve with different height to diameter ratios for all the samples collected.

- To compare the similar properties of different specimens made for identical soil samples.

\section{METHODOLOGY}

The research was done by conducting an unconfined compression test to determine the unconfined compressive strength of the 4 soil specimen which is used to calculate the unconsolidated undrained shear strength of the clay.

\section{Sample Collection and Storage}

Undisturbed soil sample were collected at the level of 7-8 feet below ground level from the site where excavation was already going on and the sample was collected and stored in a shelby tube or in a tube. The tube closed from both side by wax. Soil sample were stored under cover in a cool room which was protected from extreme of heat and cold. These samples were stored away from any possible source of heat and not high up in the building, where warm tends to effect on the soil samples. The undisturbed soil was then cut by different height to diameter ratios. Then it was kept into Desicator [7-9].

To perform the tests the samples were collected from four different locations in Dhaka. The soil samples were collected undisturbed by Shelby tube and stored delicately for further use. The list of locations where soil samples were collected is given below:

Table-1: Location of Soil Samples

\begin{tabular}{|c|l|}
\hline No. of sample & \multicolumn{1}{c|}{ Location } \\
\hline 1 & Road \#3, Block- E, Aftabnagar, Dhaka \\
\hline 2 & Shanarpar, Siddirganaj, Narayanganj \\
\hline 3 & Jamgora, Ashulia ,Savar. \\
\hline 4 & Kunia, Targach, Gazipur \\
\hline
\end{tabular}

\section{Test Procedure}

According to the ASTM standard, the unconfined compressive strength is defined as the compressive stress at which an unconfined cylindrical specimen of soil will fail in a simple compression test. The Standard Reference under ASTM D 2166 Standard Test Method for Unconfined Compressive Strength is followed here.

\section{For Unconfined Compression Test,}

- The initial length and diameter of the specimen was measured,

- The specimen on the bottom plate of the loading was put. The upper plate to make contact with the specimen was adjusted. The load dial gauge and strain (compression) dial gauge was set at zero.

- The specimen until cracks have definitely or the stress- strain curve was past or until a vertical deformation of $20 \%$ was reached, was compressed. The load dials readings, approximately at every $1 \mathrm{~mm}$ deformation of the specimen was taken, 
- The failure pattern was sketched, the density of each sample and elasticity was determined $[10,11]$.

\section{Determinants}

The 4 samples/specimen were tested for the,

- Determination of Specific Gravity of Soil by Pycnometer,

- Determination of Moisture Content,

- Determination of Grain Size Distribution by Hydrometer,

- Determination of Liquid Limit of Soil, and
- Determination of Plastic Limit of Soil.

The above factors of the soil specimen were tested before conducting the unconfined compression test on the samples by using the necessary tools $[12$, 13].

\section{RESULTS}

The in total summarization of the experiments done above to know the index properties of our collected samples is given below in Table-2:

Table-2: Results on Laboratory Investigation for the Determinants

\begin{tabular}{|c|c|c|c|c|c|c|c|c|c|}
\hline \multirow{2}{*}{$\begin{array}{l}\text { Properties } \\
\text { Sample no. }\end{array}$} & \multirow{2}{*}{$\begin{array}{l}\text { Specific } \\
\text { Gravity }\end{array}$} & \multicolumn{3}{|c|}{ Grain size Distribution } & \multirow{2}{*}{$\begin{array}{l}\text { Classifi- } \\
\text { cation }\end{array}$} & \multirow{2}{*}{$\begin{array}{l}\text { Water } \\
\text { Content }\end{array}$} & \multirow{2}{*}{$\begin{array}{l}\text { Density } \\
\text { gm/in }\end{array}$} & \multirow{2}{*}{$\begin{array}{l}\text { Liquid } \\
\text { limit }\end{array}$} & \multirow{2}{*}{$\begin{array}{l}\text { Plastic } \\
\text { limit }\end{array}$} \\
\hline & & $\begin{array}{l}\% \text { of } \\
\text { Sand }\end{array}$ & $\begin{array}{l}\text { \% of } \\
\text { Silt }\end{array}$ & $\begin{array}{l}\text { \% of } \\
\text { Clay }\end{array}$ & & & & & \\
\hline Sample 1 & 2.64 & 2.83 & 32.32 & 62.85 & Silty-clay & 15.08 & 28.40 & 27.31 & 22.82 \\
\hline Sample 2 & 2.70 & 1.75 & 22.25 & 75.00 & Silty-clay & 32.93 & 22.75 & 54.47 & 28.19 \\
\hline Sample 3 & 2.72 & 1.27 & 25.35 & 72.88 & Silty-clay & 32.00 & 24.30 & 35.69 & 24.10 \\
\hline Sample 4 & 2.66 & 4.82 & 27.50 & 65.68 & Silty-clay & 21.16 & 27.00 & 51.56 & 26.71 \\
\hline
\end{tabular}

Table-3 and Figure-2 details the comparative analysis of the unconfined compression test for sample 1 based on different $\mathrm{H} / \mathrm{D}$ ratios.

Table-3: Comparison Result for Unconfined Compression Test for Sample 1

\begin{tabular}{|l|l|l|l|}
\hline \multirow{2}{*}{ H/D Ratios } & \multicolumn{3}{|c|}{ Sample 1 } \\
\cline { 2 - 4 } & Strength (kPa) & Failure Strain (\%) & E kPa \\
\hline 1.00 & 18.8 & 11.68 & 3.10 \\
\hline 1.25 & 23.2 & 12.85 & 3.29 \\
\hline 1.50 & 22.5 & 21.32 & 3.30 \\
\hline 1.75 & 19.1 & 18.69 & 3.18 \\
\hline 2.00 & 25.9 & 18.69 & 3.32 \\
\hline 2.25 & 24.5 & 22.20 & 3.28 \\
\hline
\end{tabular}

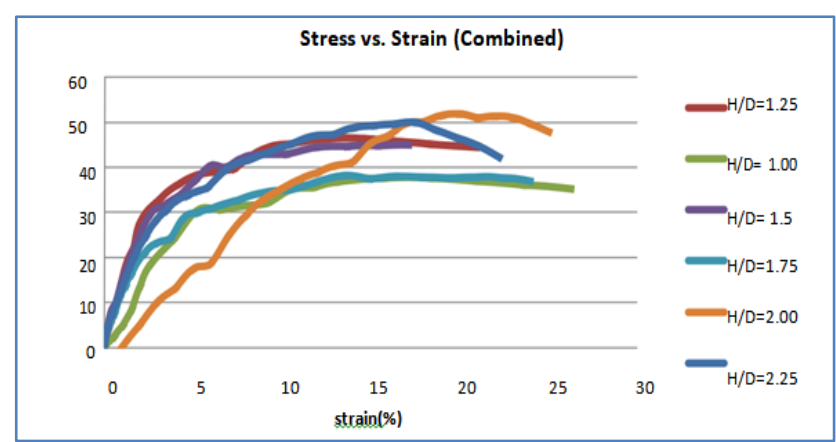

Fig-2: Comparison of Stress-Strain Curve with Different H/D Ratios for Unconfined Compression Test (Sample 1)

Table-4 and Figure-3 details the comparative analysis of the unconfined compression test for sample 2 based on different $\mathrm{H} / \mathrm{D}$ ratios.

Table-4: Comparison Result for Unconfined Compression Test for Sample 2

\begin{tabular}{|l|l|l|l|}
\hline \multirow{2}{*}{ H/D Ratios } & \multicolumn{3}{|c|}{ Sample 2 } \\
\cline { 2 - 4 } & Strength (kPa) & Failure Strain (\%) & $\mathbf{E ~ k P a}$ \\
\hline 1.00 & 23.56 & 28.27 & 7.89 \\
\hline 1.25 & 25.97 & 39.30 & 7.90 \\
\hline 1.50 & 26.27 & 41.99 & 7.88 \\
\hline 1.75 & 26.38 & No fail & 7.85 \\
\hline 2.00 & 26.92 & No fail & 7.82 \\
\hline 2.25 & 31.05 & 34.12 & 7.95 \\
\hline 2.50 & 27.76 & 39.37 & 7.91 \\
\hline
\end{tabular}




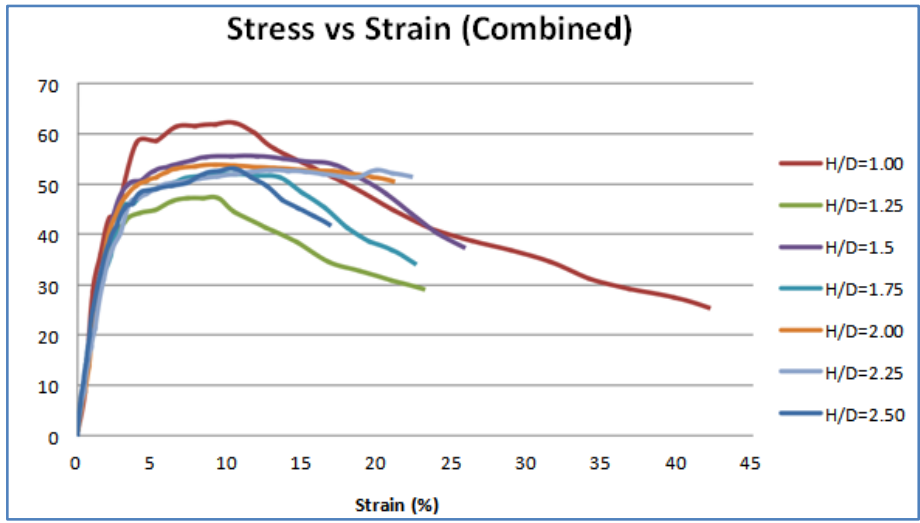

Fig-3: Comparison of Stress-Strain Curve with Different H/D Ratios for Unconfined Compression Test (Sample 2)

Table-5 and Figure-4 describe the comparative analysis of the unconfined compression test for sample 3 based on different $\mathrm{H} / \mathrm{D}$ ratios.

Table-5: Comparison Result for Unconfined Compression Test for Sample 3

\begin{tabular}{|l|l|l|l|}
\hline \multirow{2}{*}{ H/D Ratios } & \multicolumn{3}{|c|}{ Sample 3 } \\
\cline { 2 - 4 } & Strength (kPa) & Failure Strain (\%) & E kPa \\
\hline 1.00 & 17.00 & 17.12 & 2.04 \\
\hline 1.25 & 16.16 & 18.83 & 2.08 \\
\hline 1.50 & 16.67 & No fail & 2.10 \\
\hline 1.75 & 16.76 & No fail & 2.03 \\
\hline 2.00 & 18.31 & No fail & 2.05 \\
\hline 2.25 & 27.39 & No fail & 3.57 \\
\hline 2.50 & 18.83 & 30.81 & 2.07 \\
\hline
\end{tabular}

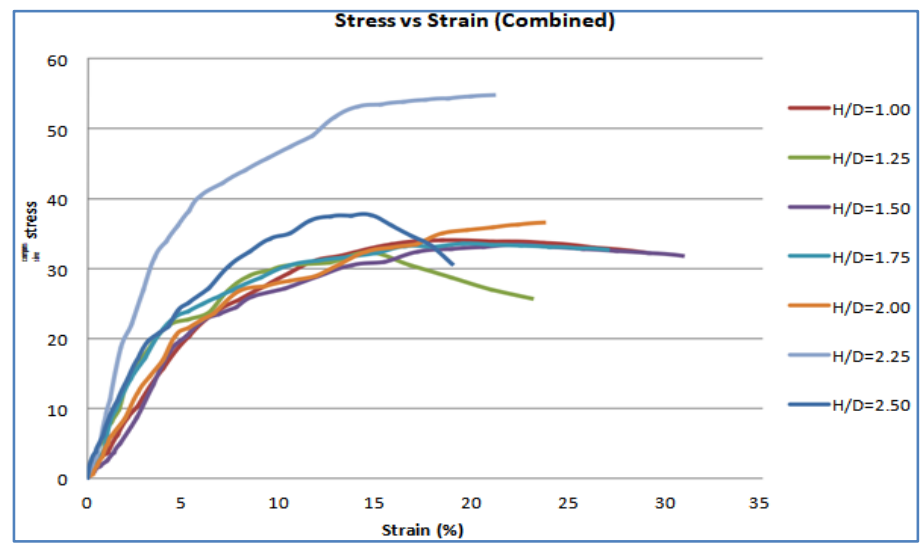

Fig-4: Comparison of stress-strain curve with different H/D Ratios for Unconfined Compression test (sample)

Table-6 and Figure-5 describe the comparative analysis of the unconfined compression test for sample 4 based on different H/D ratios.

Table-6: Comparison Result for Unconfined Compression Test for Sample 4

\begin{tabular}{|l|l|l|l|}
\hline \multirow{2}{*}{ H/D Ratios } & \multicolumn{3}{|c|}{ Sample 4 } \\
\cline { 2 - 4 } & Strength (kPa) & Failure Strain (\%) & E kPa \\
\hline 1.00 & 20.49 & No fail & 3.18 \\
\hline 1.25 & 19.45 & 29.09 & 3.19 \\
\hline 1.50 & 19.74 & 32.52 & 3.17 \\
\hline 1.75 & 23.51 & No fail & 3.16 \\
\hline 2.00 & 23.01 & 27.29 & 3.15 \\
\hline 2.25 & 25.28 & 25.68 & 3.21 \\
\hline 2.50 & 26.44 & 29.09 & 3.22 \\
\hline
\end{tabular}




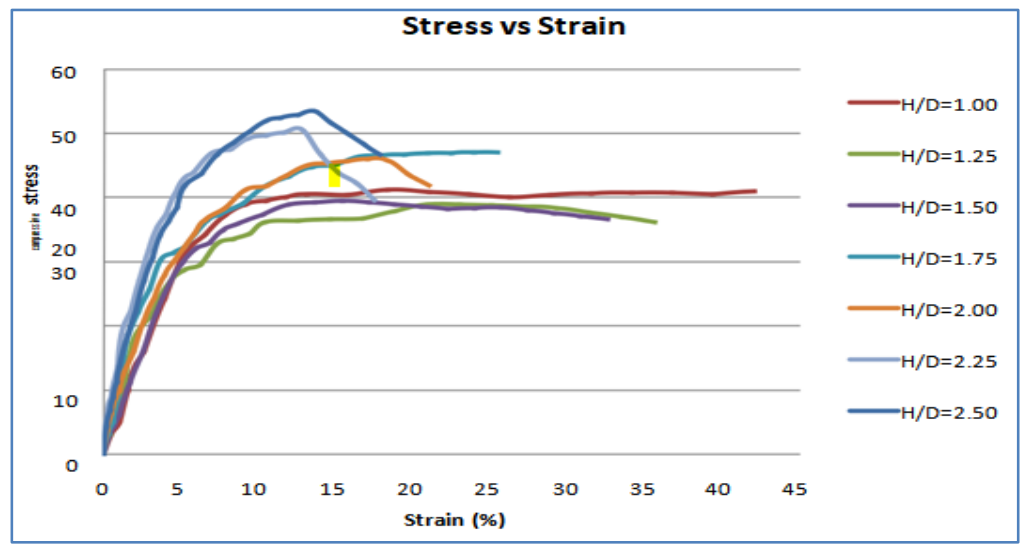

Fig-5: Comparison of stress-strain curve with different H/D Ratios for Unconfined Compression test (sample 4)

\section{DISCUSSION}

For unconfined compression test, the variation in strength of sample 1 for ratios $2.25,2.00,1.75,1.50$, $1.25,1.00$ is $24.5 \%, 25.9 \%, 19.1 \%, 22.5 \%, 23.2 \%$, $18.8 \%$ respectively. The variation in strength of sample 2 for ratios $2.50,2.25,2.00,1.75,1.50,1.25,1.00$ are $27.76 \%, \quad 31.05 \%, \quad 26.92 \%, \quad 26.38 \%$, $26.27 \%, 25.97 \%, 23.56 \%$ respectively. The variation in strength of sample 3 for ratios $2.50,2.25,2.00,1.75$, $1.50,1.25,1.00$ are $18.83 \%, 27.39 \%, 18.31 \%, 16.76 \%$, $16.67 \%, 16.16 \%, 17.00 \%$ respectively. The variation in strength of sample 4 for ratios $2.50,2.25,1.75,1.50$, $1.25,1.00$ are $26.44 \%, 25.28 \%, 23.01 \%, 23.51 \%$, $19.74 \%, 19.45 \%, 20.49 \%$ respectively.

The test results indicate that the unconfined compressive strength value decreases significantly with increasing H/D ratios.

From the combined graph of H/D ratio's we can see that the graph becomes particularly steep when the H/D exceeds 1 but then becomes less steep when the ratio of $\mathrm{H} / \mathrm{D}$ is between 1.25 and 2.50 .

The unconfined compressive strength is the compressive stress at which the specimen of soil started to fail and it is also taken as the maximum load attained per unit area or the load per unit area at $15 \%$ axial strain, which over occurs first during the performance of test.

According to relationship between consistency of clays and unconfined compressive strength the sample 1, sample 3 and sample 4 are mostly below 25 $\mathrm{kPa}$ which indicates it as very soft whereas sample 4 have values between $25 \mathrm{kPa}-50 \mathrm{kPa}$ which indicates it as soft.

Beside this, from index properties of our sample which were obtained from laboratory test more conclusions can be made:

- Within the depth of exploration, the specific gravity of the specific area ranges from 2.64 to 2.72 respectively for four samples and Grain size analysis tests revealed that, starting from few centimeters below the ground level to the depth investigate which is less than $10 \mathrm{ft}$, four soil samples are mostly silty clay contains clay content ranging from 62.85 to $75 \%$, silt fraction 22.25 to $32 \%$ and sand fraction 2.83 to $4.82 \%$.

- From atterberg limit test results, the liquid limit of the soil were 27.31, 54.47, 35.69, 51.56 respectively and plastic limit were 22.82, 28.19, $24.10,26.71$. So the plastic index would be 4.49 , $26.28,11.59$,

- 24.85 respectively $[14,15]$.

\section{CONCLUSION AND RECOMMENDATION}

Based on the study and the experimental data from previous chapters the following conclusions can be made that for unconfined compression test, the value of compressive strength decreases significantly with the increasing H/D ratio and so it can be suggested from our study that H/D ratio of soil specimens of our project ranges from 1.50-2.0 shows less variation which is almost close to the recommended ratio range.

Recommendations for the future study are outlined as follows:

- Tri-axial compression test can be performed to get a comparison of both tests and get more accurate results.

- Shear parameters, cohesion and sensitivity of soil can also be checked through few more upgraded experiments.

- Not only the ratio from 1.00 to 2.50 but also more ratios should be taken to get more proper results.

- To get more suitable range of ratio's more sample should be collected from same place and tested.

\section{REFERENCES}

1. Singh, A. (1992). Modern geotechnical engineering. Third Edition. CBS Publishers \& Distributor Pvt. Ltd., 4596/1 A, 11DARYAGANJ, NEW DELHI-110002.

2. Murthy, V. N. S. (1992). Soil mechanics and foundation engineering. Revised and Enlarged, 
Third Edition, Published by SaiKirpa Technical Consultants, "Sharada", 1692, 15th Main, 30 Cross, Banashankari Second Stage, Bangalore560070 .

3. Punmia, B. C. (1994). Soil mechanics and foundations, Thirteenth Edition, published by LAXMI PUBLICATIONS (P) LTD. 7/21 Ansari Road, Daryaganj, New Delhi-110002.

4. Lambe, T. W. (1951). Soil testing for engineers. Fully Revised \& Upgrade, Edition. Published by Wiley Eastern Limited, 72(5), 406).

5. Das, B. M. Principles of Geotechnical Engineering, 7th Edition, Engineering Properties of Soils Based on Laboratory Testing, Prof. Krishna Reddy, UIC.

6. Abbasi, N., Javadi, A. A., \& Bahramloo, R. (2012). Prediction of compression behaviour of normally consolidated fine-grained soils. World Applied Sciences Journal, 18(1), 6-14.

7. American Society for Testing and Material, 'D2435'. (2003). 'Standard test method for onedimensional consolidation properties of soils.

8. British Standard, BS1377: Part 5. (1990) 'Methods of tests for soils for civil engineering purposes - Compressibility, permeability and durability tests'.

9. P. Morris and D. Lockington. 'Geotechnical Compressibility and consolidation parameters and correlations for remoulded fine-grained marine and riverine sediments' Research Report, CRC for Sustainable Tourism.

10. A. Singh and S. Noor. 'Soil Compression Index Prediction Model for Fine-grained soils' International Journal of Innovations in Engineering and Technology (IJLTET), 2012, 1(4), Pp.34-37

11. ASTM D 2166 - Standard Test Method for Unconfined Compressive Strength of Cohesive Soil.

12. ASTM D 422-63: Standard Test Method for Particle-Size Analysis of Soils.

13. ASTM D 4318 - Standard Test Method for Liquid Limit, Plastic Limit, and Plasticity Index of Soils.

14. ASTM D 854-00 - Standard Test for Specific Gravity of Soil Solids by Water Pycnometer.

15. ASTM D 854-02: Standard Test Methods for Specific Gravity of Soil Solids by Water Pycnometer. 